\title{
BARLEY $\alpha$-AMYLASE/SUBTILISIN INHIBITOR. II. N-TERMINAL AMINO ACID SEQUENCE AND HOMOLOGY WITH INHIBITORS OF THE SOYBEAN TRYPSIN INHIBITOR (KUNITZ) FAMILY
}

\author{
by \\ JØRN HEJGAARD1), IB SVENDSEN2), and JOHN MUNDY3)4) \\ 1)Department of Biochemistry and Nutrition, \\ Technical University of Denmark, DK-2800 Lyngby \\ 2)Department of Chemistry, Carlsberg Laboratory, \\ Gamle Carlsberg Vej 10, DK-2500 Copenhagen Valby \\ 3)Department of Biotechnology, Carlsberg Research Laboratory, \\ Gamle Carlsberg Vej 10, DK-2500 Copenhagen Valby \\ 4)Institute of Biochemical Genetics, Copenhagen University, \\ Øster Farimagsgade 2A, DK-1353 Copenhagen K.
}

Keywords: Enzyme inhibition, a-amylase, subtilisin, soybean trypsin inhibitor (Kunitz), amino acid sequence homology, protease inhibitor

An inhibitor of barley malt $\alpha$-amylase 2 isolated from barley malt and a specific inhibitor of subtilisin isolated from barley have been sequenced by automatic Edman degradation. The sequence of the first $40 \mathrm{~N}$-terminal amino acids is the same for both proteins. The sequence is: Ala-Asp-Pro-Pro-Pro-Val-His-Asp-Thr-Asp-Gly-HisGlu-Leu-Arg-Ala-Asp-Ala-Asn-Tyr-Tyr-Val-Leu-Ser-Ala-Asn-Arg-Ala-His-Gly-Gly- X -Leu-Thr-Met-Ala-ProGly- X -Gly-. The $x$-amylase/subtilisin inhibitor is homologous with Kunitz-type protease inhibitors of leguminous seeds. It is also homologous with a rice subtilisin inhibitor ( 16 of the 24 residues sequenced in identical positions).

\section{INTRODUCTION}

It is well known that barley seeds contain large amounts of low molecular weight protease inhibitors and very little $\alpha$-amylase inhibitor while seeds of the closely related cereal, wheat, are rich in amylase inhibitors and relatively low in protease inhibitors. Recently ODAN et al. (10) suggested a structural homology between the major barley trypsin inhibitor and two homologous wheat inhibitors of animal $\alpha$-amylases from a comparison of their $\mathrm{N}$-terminal sequences. In the first paper of this series it was, however, shown by MUNDY et al.(8) that an inhibitor of endogenous barley $\alpha$-amylase 2 is identical with a specific inhibitor of subtilisin previously characterized by Yoshikawa et al. (14).

To our knowledge, the barley $\alpha$-amylase/subtilisin inhibitor is the first plant inhibitor of an endogenous $\alpha$-amylase as well as the first protein inactivating two entirely unrelated enzymes to be sequenced. The purpose of the present paper 
is to present a sufficiently long N-terminal sequence of this inhibitor to elucidate its possible relation to other plant $\alpha$-amylase and protease inhibitors that have been previously sequenced.

\section{MATERIALS AND METHODS}

\subsection{Isolation of the inhibitors}

The $\alpha$-amylase inhibitor was isolated from commercial green malt (Hordeum vulgare, cv. Gula) by glycogen precipitation and ion-exchange chromatography as described by MUNDY et al. (8).

The subtilisin inhibitor was isolated from barley (Hordeum vulgare, cv. Bomi mutant 1508) by ion-exchange chromatography and gel filtration essentially as described by YoshIKAWA et al. (14). The content of the inhibitor was found to be 3-4 fold higher in this high-lysine barley mutant than in normally cultivated varieties. The purity of the inhibitor was controlled by sodium dodecyl sulphate polyacrylamide gel electrophoresis (MW 20,000) and isoelectric focusing ( $\mathrm{pI}$ 7.3) using a negative-staining procedure as described by HesGaARD (1). A comparison of the amino acid compositions and N-terminai residues (Ala) established that the isolated subtilisin inhibitor is identical with that characterized by YoshIKAWA et al. (14).

\subsection{N-terminal sequence determination}

40nMole of each inhibitor (approximately $1.1 \mathrm{mg}$ protein) was sequenced from the $\mathrm{N}$-terminal by automatic Edman degradation in a Beckman Sequencer as previously described (13).

\section{RESULTS AND DISCUSSION}

\subsection{Sequence determination}

$\mathrm{N}$-terminal sequencing of the two inhibitor preparations proceeded through 40 cycles with a repetitive yield of $96 \%$. Identical sequences were obtained (Figure 1, sequence 7). The residues in positions 32 and 39 were unidentified in both experiments.

\subsection{Comparison of sequences}

$\mathrm{N}$-terminal sequences of inhibitors compared with the barley $\alpha$-amylase/subtilisin inhibitor are included in Figure 1. The barley $\alpha$-amylase/subtilisin inhibitor was found to be homologous with five seed protease inhibitors characterized from plants of the three sub-families of the Leguminosae (sequences 1-5). These inhibitors, which have all been shown to belong to the soybean trypsin inhibitor (Kunitz) family (7), also have molecular weights similar to that of the barley inhibitor (MW 19,000-22,000). Some of the leguminous inhibitors contain two peptide chains (9) which have, apparently, been produced by proteolytic cleavage of an originally synthesized peptide chain of MW 20,000. The five inhibitors have different specificities towards various proteases. The possiblity, however, that they possess inhibitory activity towards endogenous $\alpha$-amylases has not, to our knowledge, been investigated.

A higher degree of sequence homology was found between the barley inhibitor and a subtilisin inhibitor isolated by KaTO et al. (5) from rice (sequence 6). Twenty-four $\mathrm{N}$-terminal residues of the inhibitor have been sequenced of which 16 were found in the same positions as in the barley inhibitor. The characteristic Pro-ProPro sequence near the $\mathrm{N}$-terminal has only been found in these two inhibitors. This high degree of homology suggests that the rice subtilisin inhibitor may also function as an inhibitor of endogenous rice $\alpha$-amylase. The possibility that very similar inhibitors are present in other cereals, including wheat and rye, has been suggested by Mundy et al. (8).

ODani et al. (10) have sequenced the $40 \mathrm{~N}$ terminal residues of a major barley trypsin inhibitor with a molecular weight of 14,000 (sequence 8 ). From a comparison of the sequences of only the first 23 residues, they found some homology with the sequences of two homologous wheat $\alpha$-amylase inhibitors $(0.19$ and 0.28$)$ of similar molecular weight (sequences 9-10). These wheat inhibitors have been shown to inactivate $\alpha$-amylases from various animals but not from germinated wheat $(11,12)$. On the other hand, a comparison of the subsequent sequence of residues 20 to 40 of the barley trypsin inhibitor with the complete sequence of the major wheat $\alpha$-amylase inhibitor $(0.28)$ obtained by KaSHLAN and RichaRDSON (4) shows very little homology between these two proteins. In fact, a similar, slight homology exists between the first 40 residues of the barley trypsin inhibitor and the barley $\alpha$-amylase/subtilisin inhibitor (se- 

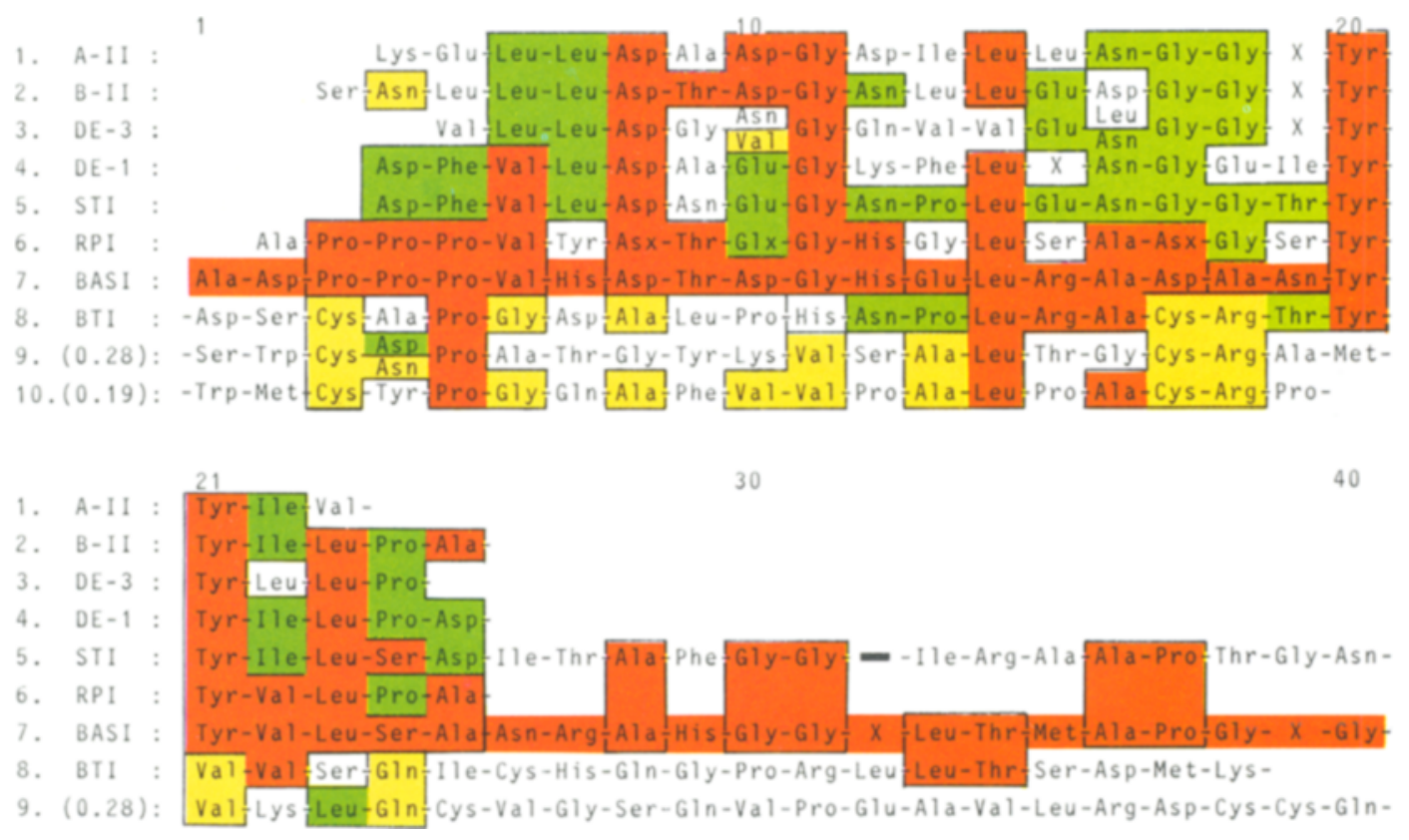

Figure 1. Amino acid sequence of the $40 \mathrm{~N}$-terminal residues of the barley $x$-amylase/subtilisin inhibitor (sequence 7).

The sequence is compared with five leguminous seed inhibitors from the soybean trypsin inhibitor (Kunitz) family (sequences 1-5), with a rice subtilisin inhibitor (sequence 6), with the major barley trypsin inhibitor (sequence 8 ), and with wheat $x$-amylase inhibitors (sequences $9-10$ ). Sequences 8 -10 were previously compared by ODANI et al.(10). The first 2-4 amino acids of these three sequences are not shown. For comparisons, homologous sequences are both boxed and colour coded: Red, sequence of the barley $x$-amylase/subtilisin inhibitor and homology with other inhibitors; Green, homology between legume Kunitz-type inhibitors; Orange, homology between barley trypsin and wheat $x$-amylase inhibitors. X denotes unidentified residues and - indicates a "gap" introduced in the soybean inhibitor sequence to obtain maximal homology with the barley $x$-amylase/subtilisin inhibitor. The residue numbering refers to the sequence of the barley $x$-amylase/subtilisin inhibitor (sequence 7). Inhibitor codes: A-II and B-II: Albizzia julibrissin protease inhibitors (9). DE-3: Erythrina latissima trypsin inhibitor (3). DE-1: Peltophorum africanum protease inhibitor (2). STI: soybean Kunitz trypsin inhibitor (6). RPI: rice subtilisin inhibitor (5). BASI: Barley $x$-amylase/subtilisin inhibitor. BTI: barley trypsin inhibitor (10). (0.28): wheat $x$-amylase inhibitor $(4,12)$. (0.19): wheat $x$-amylase inhibitor $(11)$.

quences $7-8$ ). In 8 positions of the 11 residue sequence between amino acids 12 and 22 , the barley trypsin inhibitor (sequence 8 ) contains the same amino acid as either the barley $\alpha$ amylase/subtilisin inhibitor (sequence 7) or the soybean inhibitor (sequence 5). Further evidence for a general relation between $\alpha$-amylase and protease inhibitors may appear when the complete sequences of both of the barley inhibitors are available. At present it can be concluded, however, that a barley inhibitor of both an endogenous $\alpha$-amylase and of a microbial serine protease belong to the same inhibitor family as the well characterized soybean Kunitz-type inhibitor.

\section{ACKNOWLEDGEMENTS}

The authors wish to thank SUSANNE JENSEN for her skilled help in purifying the subtilisin inhibitor and LONE SøRENSEN for technical assistance with the sequencing work.

NOTE ADDED IN PROOF:After acceptance of the present communication, "The complete amino acid sequence of the bifunctional $\alpha$-amylase/ trypsin inhibitor from seeds of ragi (Indian finger millet)" has been published (CAMPOS, F.A.P. \& M. RichaRdSON: FEBS Letters, 152, 300-304, 1983). This inhibitor of animal salivary and pancreatic amylases is clearly homologous with both the barley trypsin inhibitor and the wheat $\alpha$ - 
amylase inhibitors discussed by ODANI et al. (10) and above (Figure 1). Thus, the existence of bifunctional inhibitors possessing activity towards both serine proteases and $\alpha$-amylases has now been established within two different plant inhibitor families.

\section{REFERENCES}

1. HeJGAARD, J.: Isoelectric focusing of subtilisin inhibitors: Detection and partial characterization of cereal inhibitors of chymotrypsin and microbial proteases. Anal. Biochem. 116, 444449 (1981)

2. JOUBERT, F.J.: Purification and some properties of a proteinase inhibitor (DE-1) from Peltophorum africanum (Weeping wattle) seed. Z. Physiol. Chem. 362, 1515-1521 (1981)

3. Joubert, F.J., F.H.H. CarlsSON \& T. HaYletT: Purification and some properties of two proteinase inhibitors (DE-1 and DE-3) from Erythrina latissima (broad- leaved Erythrina) Seed. Z. Physiol. Chem. 362, 531-538 (1981)

4. Kashlan, N. \& M. Richardson: The complete amino acid sequence of a major wheat protein inhibitor of $\alpha$-amylase. Phytochem. 20, 17811784 (1981)

5. Kato, I., N. Tominaga \& F. Kihara: In Proceedings of the 23rd conference on protein structure. (Iwai, K. ed.) pp. 53-56 (in Japanese) (1972)

6. Koide, T. \& T. Ikenaka: Studies on soybean trypsin inhibitors 3. Amino-acid sequence of the carboxyl-terminal region and the complete amino-acid sequence of soybean trypsin inhibitor (Kunitz). Eur. J. Biochem. 32, 417-431 (1973)

7. Laskowski, M. JR. \& I. Kato: Protein inhibitors of proteinases. Ann. Rev. Biochem. 49, 593-626 (1980)

8. Mundy, J., I. Svendsen \& J. HejgaArd: Barley $x$-amylase/subtilisin inhibitor. I. Isolation and characterization. Carlsberg Res. Commun. 48, 81-90 (1983)

9. Odani, S., S. Odani, T. Ono \& T. Ikenaka: Proteinase inhibitors from a Mimosoideae legume, Albizzia julibrissin. Homologues of soybean trypsin inhibitor (Kunitz). J. Biochem. 86, 1795-1895 (1979)

10. Odani, S., T. KoIde \& T. Ono: Sequence homology between barley trypsin inhibitor and wheat $\alpha$-amylase inhibitors. FEBS Letters. 141, 279-282 (1982)

11. Petrucci, T., G. Sannia, R. Parlamenti \& V. SilANO: Structural studies on wheat monomeric and dimeric protein inhibitors of $\alpha$ amylase. Biochem. J. 173, 229-235 (1978)

12. Redman, D.G.: N-terminal amino acid sequence of wheat proteins that lack phenylalanine and histidine residues. Biochem. $\mathrm{J}$. 155, 193-195 (1976)

13. Svendsen, I., B. Martin \& I. Jonassen: Characteristics of Hiproly barley III. Amino acid sequences of two lysine-rich proteins. Carlsberg Res. Commun. 45, 79-85 (1980)

14. Yoshikawa, M, T. Imasaki, M. Fujil \& $\mathrm{M}$. OOGAKI: Isolation and some properties of a subtilisin inhibitor from barley. J. Biochem. 79, 765-773(1976) 